\title{
THE EFFECT OF ORGANIZATIONAL CULTURE ON SELF-CONCEPT AND DISCIPLINE TOWARD SELF-REGULATED LEARNING
}

\author{
Fawziah Zahrawati ${ }^{1}$, Maryadi $^{2}$, Muhammad Idris ${ }^{3}$, Didiek Handayani Gusti ${ }^{4}$, Asri $^{5}$, \\ Andi Aras 6 \\ ${ }^{1,6}$ Institut Agama Islam Negeri (IAIN) Parepare, 2,3,4,5STIE Nobel Indonesia Makassar \\ 1,6Jalan Amal Bhakti No.8, Bukit Harapan, Kec. Soreang, Kota Parepare, \\ 2,3,4,5Jalan Sultan Alauddin No. 212, Mangasa, Kota Makassar \\ Email: zahraburhan42@gmail.com¹, ahmadmaryadi@gmail.com², \\ muhammadidris709@gmail.com³ ${ }^{3}$ didiek@stienobel-indonesia.ac.id4, \\ drasriwanwo01@gmail.com ${ }^{5}$, andiaras@iainpare.ac.id ${ }^{6}$
}

\begin{abstract}
:
This study aims to determine the various factors that affect students' self-regulated learning, especially the effects of self-concept, discipline, self-concept and discipline moderated by organizational culture on self-regulated learning. This research was quantitative research. The population was all students of Tarbiyah Faculty of IAIN Parepare in 2016-2019, consisting of 2000 students. The sample was 125 students. Data were collected using questionnaires and documentation, which were then analyzed using SmartPLS. The results showed that 1) there was a positive and significant effect of self-concept toward self-regulated learning with t-statistic $4.514>$ $t$ table $1.96 ; 2$ ) there was no positive and significant effect of discipline toward selfregulated learning with t-statistic $0.688<$ t table 1.96; 3) organizational culture was unable to moderate the effect of self-concept toward self-regulated learning with $t$ statistic $0.198<$ t table $1.96 ; 4$ ) organizational culture was unable to moderate the effect of discipline toward self-regulated learning with $\mathrm{t}$-statistic $0.514<\mathrm{t}$ table 1.96 . Therefore, paying attention to students' self-concepts was important because students who had positive self-concepts could develop their potential and self-regulated learning.
\end{abstract}

\begin{abstract}
Abstrak:
Penelitian ini bertujuan untuk mengetahui berbagai faktor yang mempengaruhi pembelajaran mandiri mahasiswa, khususnya untuk mengetahui pengaruh konsep diri, disiplin, konsep diri dan disiplin yang dimoderasi oleh budaya organisasi terhadap pembelajaran mandiri. Penelitian ini merupakan penelitian kuantitatif. Populasi penelitian ini adalah seluruh mahasiswa Fakultas Tarbiyah IAIN Parepare tahun 2016-2019 yang berjumlah 2000 mahasiswa. Sampel penelitian ini sebanyak 125 mahasiswa. Data dikumpulkan menggunakan menggunakan kuesioner dan dokumentasi yang selanjutnya dianalisis menggunakan SmartPLS. Hasil penelitian menunjukkan bahwa 1) terdapat pengaruh yang positif dan signifikan pada konsep diri terhadap pembelajaran mandiri dengan t-hitung 4,514 $>\mathrm{t}$ tabel 1,96,2) tidak ada pengaruh positif dan signifikan disiplin terhadap pembelajaran mandiri dengan $t$ hitung $0,688<\mathrm{t}$ tabel 1,96,3) budaya organisasi tidak mampu memoderasi pengaruh konsep diri terhadap pembelajaran mandiri dengan t-hitung 0,198 $<\mathrm{t}$ tabel 1,96, 4) budaya organisasi tidak mampu memoderasi pengaruh disiplin terhadap pembelajaran mandiri dengan t-hitung $0,514<t$ tabel 1,96 . Oleh kare itu, perhatian terhadap konsep diri mahasiswa perlu karena mahasiswa yang memiliki konsep diri positif akan memiliki kemampuan untuk mengembangankan potensi dan pembelajaran mandiri yang baik.
\end{abstract}




\section{Keywords:}

Self Concept, Discipline, Self-Regulated Learning, Organizational Culture

How to Cite: Zahrawati, F., Maryadi, Idris, M., Gusti, D. H., Asri, \& Aras, A. (2021). The Effect of Organizational Culture on Self-Concept and Discipline toward Self-Regulated Learning. Lentera Pendidikan : Jurnal Ilmu Tarbiyah dan Keguruan, 24(2), 290-302. https://doi.org/10.24252/lp.2021v24n2i11.

\section{INTRODUCTION}

The presence of the Covid-19 pandemic is a challenge for all areas of human life, including education. In the field of education, the government issued an online learning policy as an effort to achieve educational goals and also broke the chain of spreading this pandemic (Sulisworo, Fitrianawati, Maryani, Hidayat, Agusta, \& Saputri, 2020). Implementation of the online learning process can not be separated from a variety of obstacles, both the availability of resources and the ability of students to manage their learning process (Zahrawati \& Nurhayati, 2021; Zahrawati \& Ramadani, 2021). With this online learning policy, students are required to be able to manage their learning process well. They must make a good study plan and schedule to join online classes and submit assignments on time, control and evaluate themselves to find out how far their learning goals have been achieved. Therefore, students must have good self-regulated learning to undergo the learning process during the Covid-19 pandemic.

Self-regulated learning is a concept of self-management and an approach of the learning process that emphasizes cognitive and metacognitive approach strategies (Kalenda \& Vávrová, 2016; Savoji, Niusha, \& Boreiri, 2013; Kareshki, 2011; Cazan, 2012; Jakešová \& Kalenda, 2015; Fettahlioğlu, 2011; Zahrawati, 2020). Self-regulated learning is something that does not escape the attention of academics and practitioners in the realm of education because of its effect on academic achievement. As a result, several studies state a positive correlation between self-regulated learning and learning achievement (Savoji, Niusha, \& Boreiri, 2013; Cazan, 2012).

In addition, several studies had also found that low self-regulated learning increased procrastination or delayed in tasks which ultimately have an impact on decreasing academic achievement (Motie, Heidari, \& Sadeghi, 2012; Fasikhah \& Fatimah, 2013; Pintrich, 2000). Therefore, self-regulated learning is very important for someone to improve their academic performance.

Based on the influence of self-regulated learning, Zimmerman (1989) stated that 3 things affected a person's self-regulated learning, including a) individuals, which consist of personal knowledge, level of metacognition ability, goals to be achieved, and selfefficacy beliefs, b) behavior which includes behavior, personal, and environmental self reactions, c) the environment which is an influence that comes from outside a person. This environmental influence is in the form of enactive experience, social support, and others. This study focuses on self-concept and discipline as moderated by organizational culture as factors that influence student self-regulated learning at Tarbiyah Faculty of IAIN Parepare. 
Self-concept is very important in developing a person's personality and behavior, as Desmita (2012) states that a person's behavior is determined by self-concept. The overall behavior of a person is a representation of the view of self-reflection. Behavior and selfview will go hand in hand. If someone views himself/herself can act by setting goals first, regulate to achieve goals, have time management, have physical and social environment, that person has good self-regulated learning.

Discipline as an internal factor is a person's ability to control behavior (Drever, 1986). Besides, Hurlock (1993) states that discipline aims to behave following the values and norms that apply in the group to know their role. Self-regulated learning and discipline have a significant relationship. If someone has high self-regulated learning, it will be in line with their discipline.

Organizational culture is an external factor moderating the effect of self-concept and discipline toward self-regulated learning. It has the power to influence student behavior. In the context of IAIN Parepare, there is a unique organizational culture with the motto malebbi warekkadanna makkiade ampena (polite in speech, civilized in action), campus residents have a foundation to speak and behave. With a vision of acculturation of culture and Islam, IAIN Parepare exists with its distinctive characteristics that not only strive to provide superior and competitive education, teaching, research and community service but also as a center for strengthening aqidah (faith) and akhlaqul karimah (character). It makes the organizational culture at Tarbiyah Faculty of IAIN Parepare interesting to study its effects on self-regulated learning.

During several months of conducting online lectures, information was obtained that students tend to be unable to manage time in the learning process. It can be seen from their inability to attend online lectures and submit assignments on time. Some students ask for time extensions when they want to submit academic assignments. In addition, some of the tasks they submit just copy and paste. It indicates that students do not have good selfregulated learning abilities.

The difference between the expected ideal conditions and the facts of the selfregulated learning of Tarbiyah Faculty students at IAIN Parepare is still low. This study aims to find factors that influence self-regulated learning. The research objectives of this study are to determine the effects of self-concept, discipline, self-concept and discipline moderated by organizational culture on students' self-regulated learning.

\section{RESEARCH METHOD}

This study aimed to see the effect of self-concept and discipline moderated by organizational culture toward self-regulated student learning. This research used a quantitative approach. The population in this study were all active students of Tarbiyah Faculty of IAIN Parepare academic in 2016-2019. There are 2000 students spread across eight study programs. This study used a questionnaire and documentation to collect data on self-concept, discipline, organizational culture and self-regulated learning. The sample size in the Multivariate Analysis refers to the opinion of Hair, Black, Babin, \& Anderson (2014), which is the minimum number of observations (samples) for each research 
indicator, namely five times or its multiple. In this study, 25 indicators spread over four variables; self-concept, discipline, organizational culture, and self-regulated learning. Therefore, the sample size in this study was 125 students.

Each variable has its indicators. Self-concept indicators are academic selfknowledge, non-academic self-knowledge, academic self-expectations, non-academic selfexpectations, academic self-assessment, and non-academic self-assessment (Labhane \& Baviskar, 2015; Desmita, 2012). The indicators for the discipline variable are: 1) being on time for lecture activities, 2) being on time for completing assignments or lecture projects, 3) being obedient to the appearance on campus, 4) being obedient to the lecture contract, and 5) being obedient to campus rules and regulations (Prijodarminto, 1994; Subari, 1994; Drever, 1986). Indicators of organizational culture variables are campus physical environment, campus rules, various habits, campus vision and mission, attitudes held by campus residents, mottos, relationships between campus residents, and belief patterns (Mihaela \& Bratianu, 2012; Ozan \& Demir, 2012; Deal \& Peterson, 2009; Lunenburg, 2011; George \& Jones, 2005). Indicators of self-regulated learning variables are 1) positive attitude in the learning process and desire to achieve success, 2) diligence and desire to try, 3) concentration and attention on academic tasks, 4) managing time in doing academic assignments, 4) self-reflection, reviewing learning, and preparing to take part in learning, and 5) selecting ideas and information that are considered essential (Mukhid, 2008; Zimmerman, 1989; Pintrich, 2000; Risemberg, 1997; Pintrich \& Groot, 1990; Schunk \& Zimmerman, 1998; Bandura, 1977; Corno \& Mandinach, 1983).

The validity test used to measure the validity of the questionnaire was construct validity. This study also used SmartPLS. The validity test is carried out using evaluation measurement (outer), namely the convergent validity of the loading factor for each $>0.50$ to the target variable. In addition, another validity test was also conducted by looking at and comparing discriminant validity and the square root of average variance extracted (AVE). If the score is higher than the correlation value between the constructs, good discriminant validity is achieved (if AVE $>0.5$ ). Furthermore, the approach used to determine the reliability of the instruments in this study was the internal consistency approach with the Cronbach Alpha technique. Instrument reliability criteria if the minimum value was in the high category (0.70). The research hypothesis testing was carried out using SmartPLS by looking at the P Values.

\section{RESULTS AND DISCUSSION}

\section{Evaluation of Validity and Reliability Tests}

Evaluation of validity and reliability tests is carried out on the data that has been obtained. The validity test in this study was carried out by using an evaluation measurement (outer) model, namely the convergent validity, the loading factor for each > 0.50 to the target variable. From the results of convergent validity, some items did not meet the criteria, so that the items were issued. There was 1 item issued in the self-concept, discipline, self-regulated learning, and 3 items in the organizational culture. In addition, the validity test was also carried out by comparing the discriminant validity and the square root of average variance extracted (AVE). 
Based on the results of measurements with AVE on each indicator, it was found that the AVE value in this study was $>0.50$. On validity testing through convergent validity and discriminant validity, it was obtained: 6 valid items to measure self-concept variables, 8 valid items to measure discipline, 10 valid items to measure organizational culture, and 9 valid items to measure self-regulated learning. Furthermore, the reliability test was carried out by looking at the composite reliability value and based on the study results. It was found that the composite reliability value was $>0.80$, which indicated that all variables were appropriate and suitable to be used as the tested variable. In addition, the reliability test was also carried out by looking at the Cronbach alpha value. The results found that each instrument variable in this study had a Cronbach alpha value $>0.70$. The following Figure 1 presents the outer model of the validity and reliability test results.

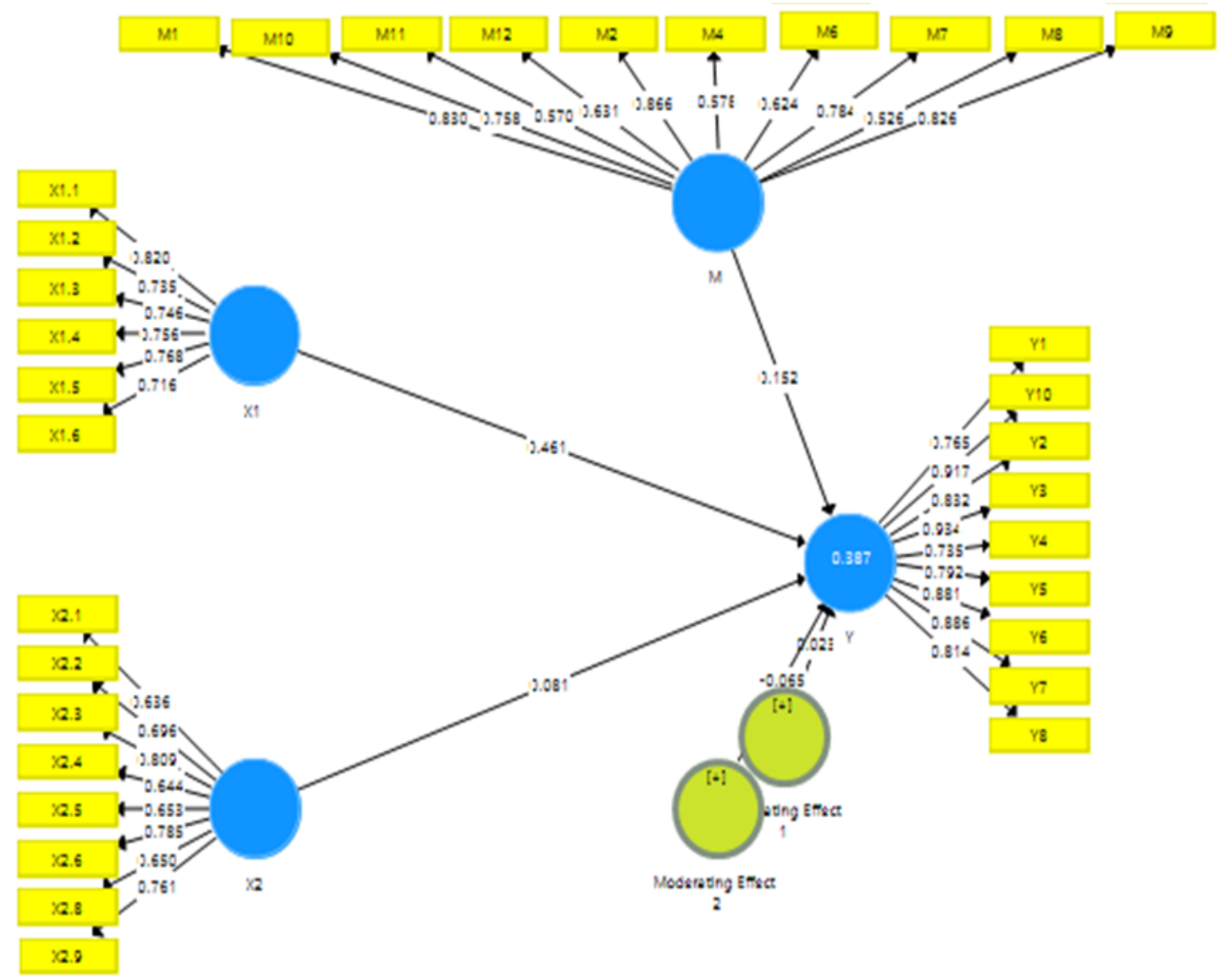

Figure 1. The Outer Model of The Validity and Reliability Test Results

Furthermore, data analysis was conducted to determine the effect of self-concept and discipline moderated by organizational culture toward self-regulated learning. The following Table 1 summarizes the results of bootstrapping. 
Table 1. The Results of Bootstrapping

\begin{tabular}{cccccc}
\hline & $\begin{array}{c}\text { Original } \\
\text { Sample (O) }\end{array}$ & $\begin{array}{c}\text { Sample } \\
\text { Mean (M) }\end{array}$ & $\begin{array}{c}\text { Standard } \\
\text { Deviation } \\
\text { (STDEV) }\end{array}$ & $\begin{array}{c}\text { T Statistics } \\
(\mid \mathbf{O} / \text { STDEV|) }\end{array}$ & P Values \\
\hline M -> Y & 0.152 & 0.172 & 0.084 & 1.809 & 0.071 \\
\hline $\begin{array}{l}\text { Moderating } \\
\text { Effect 1 - > Y }\end{array}$ & 0.023 & 0.047 & 0.118 & 0.198 & 0.843 \\
\hline $\begin{array}{l}\text { Moderating } \\
\text { Effect 2 -> Y }\end{array}$ & -0.065 & -0.077 & 0.126 & 0.514 & 0.608 \\
\hline $\mathbf{X 1 ~}->$ Y & 0.461 & 0.447 & 0.102 & 4.514 & 0.000 \\
\hline $\mathbf{X 2 ~}->$ Y & 0.081 & 0.088 & 0.117 & 0.688 & 0.492 \\
\hline
\end{tabular}

\section{The Effect of Self Concept toward Self-Regulated Learning}

The study results found that the self-concept of students at Tarbiyah Faculty of IAIN Parepare, which includes self-knowledge, self-expectations, and self-assessment, both academic and non-academic, were in the very good category. In addition, this study also found that self-concept had a significant positive effect on students' self-regulated learning at Tarbiyah Faculty of IAIN Parepare. It could be seen from 0.461 of the original sample value, 4.514 of t-statistic, and 0.000 of P-value. The measurement results showed t-statistic $>$ t-table $(5 \%$ significance level $=1.96)$ and $\alpha \leq 0.05$, so the first hypothesis in this study was accepted.

Self-concept and self-regulated learning had a positive relationship direction. In this regard, it could be interpreted that the higher the student's self-concept, the higher the self-regulated learning. This finding aligned with Bandura's Social Learning Theory (1977), which stated that self-regulation was related to self-concept. It was further explained that someone who had a negative self-concept tended to rate himself/herself as a lowly person. Conversely, someone with a positive self-concept tended to assess himself/herself positively. In connection with the learning process, self-concept affects students' self-regulated learning because self-concept includes their views on their selfimage. If students have positive knowledge, expectations, and assessments of themselves, then they would be able to plan, organize, and evaluate well the learning process (Rosenberg \& Kaplan, 1982).

The results of this study are also in line with several previous research results that show that self-concept affects self-regulated learning, which in turn affects academic competence, high educational and career aspirations, and academic achievement (Sangeeta \& Sumitra, 2012; Nalah, 2014; Soufi, Damirchi, Sedghi, \& Sabayan, 2014). Students who have a positive self-concept will know their strengths and weaknesses, have expectations for achievement and be useful for others, and have an assessment that they can become outstanding students. It drives the formation of good self-regulated learning. Thus, students will be diligent and desire to try, have attention to academic and nonacademic activities, manage time well, and reflect on themselves for better achievement. 


\section{The Effect of Discipline toward Self-Regulated Learning}

This study found that student discipline at Tarbiyah Faculty of IAIN Parepare was very good category. Discipline includes being obedient to time in attending lecture activities, being obedient to time in completing assignments or lecture projects, being obedient to appear on campus, obeying lecture contracts, and being obedient to campus rules. In addition, this study also found that discipline did not significantly affect student self-regulated learning at Tarbiyah Faculty of IAIN Parepare. It could be seen from these results; 0.081 of the original sample value, 0.688 of $\mathrm{t}$-statistic, and 0.492 of P-value. The measurement results showed that the $\mathrm{t}$-statistic $<\mathrm{t}$-table $(5 \%$ significance level $=1.96)$ and $\alpha>0.05$, then the second hypothesis in this study was rejected.

Discipline had no significant effect on self-regulated learning, which was not in line with the opinion of Drever (1986) and Hurlock (1993). Someone who had a disciplined attitude will have the awareness to obey the rules that apply in his community. Based on categorization, student discipline was very good category. Still, if observed on each variable indicator, it appeared that students were not on time in doing assignments or projects given by lecturers and in attending classes which indicated discipline did not affect self-regulated learning. In addition, another thing that caused the discipline not to affect self-regulated learning was the value of the influence contribution given by the independent variable to the dependent variable was $38.7 \%$. It indicated that there were other variables outside the research variables that affect self-regulated learning, namely: level, gender, self-efficacy, and strategy use (Zimmerman \& Martinez-Pons, 1990; Usher \& Pajares, 2008), academic emotions (Pekrun, Goetz, Titz, \& Perry, 2002), implementation of problem-based learning (Sungur \& Takayya, 2006), epistemic beliefs (Muis, 2007), use of management systems e-learning courses (Vovides, Sanchez-Alonso, Mitropoulou, \& Nickmans, 2007), students' tutorial system perception and academic self-efficacy (Mulyadi, Basuki, \& Rahardjo, 2016).

The results of this study were also not in line with the results of previous studies, which stated that discipline affects self-regulated learning. Someone who had good discipline would manage their learning well (Harahap \& Neviyarni S, 2018; Permana \& Latifah, 2015). Although the discipline did not affect self-regulated learning, there is a relationship between the two. Very good discipline students could be seen from their obedience to attend lecture activities, obedience to complete assignments or projects, adherence to performance procedures on campus, adherence to lecture contracts that have been mutually agreed upon at the beginning of lecture, and adherence to the rules and regulations is on campus.

\section{The Effect of Self Concept Moderated by Organizational Culture toward Self- Regulated Learning}

Organizational culture was unable to moderate the effect of self-concept toward selfregulated student learning at Tarbiyah Faculty of IAIN Parepare. From the results of this study, it could be interpreted that organizational culture cannot strengthen or weaken the 
influence of self-concept toward self-regulated learning. It could be seen from the scores of 0.023 of original sample value, 0.198 of t-statistic, and 0.843 of P-value. The measurement results showed that the $\mathrm{t}$-statistic Moderating effect 1 - $\mathrm{Y}<\mathrm{t}$-table $(5 \%$ significance level $=1.96$ ) or $\alpha>0.05$, it could be stated that the third hypothesis in this study was rejected.

The probability value on the moderating effect of 1 variable was not significant, and the probability value on the organizational culture variable was also not significant. It could be stated that the classification of the moderating variable was a type of potential moderation, which meant that organizational culture had the potential to strengthen or weaken the influence of self-concept toward self-regulated learning. Organizational culture did not interact with self-concept and had no significant relationship with selfregulated learning.

Based on the results of this study, it indicated that the organizational culture at Tarbiyah Faculty of IAIN Parepare had not been able to influence the self-concept intervention. This finding did not support Bandura's (1977) theory which stated that the environment (organizational culture) could shape a person's personality. Likewise, Deal \& Peterson (2009) stated that organizational culture was a complex network of traditions and rituals built by its citizens and influencing the behavior of each member of the organization. Furthermore, the results of this study were also inconsistent with several previous study findings (Pratama, Siraj, \& T, 2019; Zahrawati \& Faraz, 2017). One reason was that the organizational culture in Tarbiyah Faculty of IAIN Parepare was still in the good category. As students consider that the classroom is not comfortable for lecture activities, it cannot moderate the effect of self-concept on student self-regulated learning. In addition, the value of the influence contribution given by the independent variable to the dependent variable was $38.7 \%$ which was the basis for stating that there were still other variables outside the study that affect self-regulated learning, namely: level, gender, self-efficacy, and strategy use (Zimmerman \& Martinez-Pons, 1990; Usher \& Pajares, 2008), academic emotions (Pekrun, Goetz, Titz, \& Perry, 2002), implementation of problem-based learning (Sungur \& Takayya, 2006), epistemic beliefs (Muis, 2007), use of management systems e-learning courses (Vovides, Sanchez-Alonso, Mitropoulou, \& Nickmans, 2007), students' tutorial system perception and academic self-efficacy (Mulyadi, Basuki, \& Rahardjo, 2016).

Organizational culture is an indication of how citizens act and behave through existing rules. Organizations with a positive culture will direct their citizens to focus on activities that can improve quality so that citizens will be busy with positive activities to achieve the organization's vision and mission. Zamroni (2007) stated that organizations that had a positive culture would have the ability to face all the problems faced by their citizens, while organizations with a negative culture would find it difficult to solve the problems they face. In addition, Deal \& Peterson (2009) stated that a negative organizational culture would make its citizens focus on negative values that exist in the organization. 
Organizations with a positive culture have a conducive environment and classrooms for the implementation of learning. They always socialize the rules on campus to create an orderly atmosphere and familiarize campus residents with good relations. Students also have motivation and discipline. In addition, lecturers are present on time in class because they enjoy the learning process with students. Various positive habits exist among campus residents, such as the habit of greeting and the belief that they can achieve great achievements. Therefore, organizations that have a positive culture will make their citizens have a positive self-concept as well.

\section{The Effect of Discipline moderated by Organizational Culture toward Self Regulated Learning}

Organizational culture was unable to moderate the effect of discipline toward selfregulated learning of students. From the results of this study, it could be interpreted that organizational culture could not strengthen or weaken the effect of discipline toward selfregulated learning. It could be seen from the scores; 0.065 of the original sample, 0.514 of the $\mathrm{t}$-statistic, and 0.608 of $\mathrm{P}$-value. The measurement results indicated that the $\mathrm{t}$-statistic Moderating effect $2-Y<t$ table (5\% significance level $=1.96)$ or $\alpha>0.05$, it could be stated that the fourth hypothesis in this study was rejected.

By looking at the probability value on the Moderating effect 2 variables and the probability value on the organizational culture variable, which were not significant, it could be stated that the classification of the moderating variable was a type of potential moderation. It meant that organizational culture had the potential to strengthen or weaken the effect of discipline on self-regulated learning. Organizational culture did not interact with discipline and did not have a significant relationship with self-regulated learning.

This study indicated that the organizational culture at Tarbiyah Faculty of IAIN Parepare had not influenced disciplinary intervention. This finding did not support Bandura's (1977) theory which stated that the environment (organizational culture) could shape a person's personality. Likewise, George \& Jones (2005) stated that organizational culture was a set of shared values, beliefs, and norms that influence how to think, feel, and behave towards one another and towards people outside the organization. Furthermore, the results of this study were also inconsistent with the results of previous studies (Rusmita \& Badera, 2018) because the organizational culture in Tarbiyah Faculty of IAIN Parepare was still in the good category. As students judge that classrooms were not comfortable for lecture activities, they could not strengthen or weaken the effect of discipline on student self-regulated learning. In addition, the value of the influence contribution given by the independent variable to the dependent variable was $38.7 \%$ which was the basis for stating that there were still other variables outside the study that affect self-regulated learning, namely: level, gender, self-efficacy, and strategy use (Zimmerman \& Martinez-Pons, 1990; Usher \& Pajares, 2008), academic emotions (Pekrun, Goetz, Titz, \& Perry, 2002), implementation of problem-based learning (Sungur \& Takayya, 2006), epistemic beliefs (Muis, 2007), use of management systems e-learning courses (Vovides, Sanchez-Alonso, Mitropoulou, \& Nickmans, 2007), students' tutorial system perception and academic self-efficacy (Mulyadi, Basuki, \& Rahardjo, 2016). 


\section{CONCLUSION}

The results of this study found that: self-concept had a significant effect on student self-regulated learning, discipline did not have a significant effect on student self-regulated learning, organizational culture was unable to moderate the effect of self-concept on student self-regulated learning, and organizational culture was unable to moderate the effect of discipline on student self-regulated learning. Based on these findings, it was expected to pay attention to students' self-concepts as an effort to improve their selfregulated learning. In addition, the suggestions for the next researcher are: 1) Researchers can look for other variables outside the variables used in this study so that they can provide a broader picture of the factors that influence student self-regulated learning such as grade, motivation, gender, self-efficacy, and academic emotions. 2) The use of the questionnaire has not been able to reveal all the real conditions, so it can be added with the interview method so that the data obtained is more completed and describes the real conditions. 3) The use of the SmartPLS application in processing data has not been able to simultaneously identify the effect of the independent variable on the dependent variable by using the moderating variable to add to the use of the SPSS application. 4) The SmartPLS application in testing validity by evaluating the measurement (outer) model of the instrument using a drop system or removing items that do not have convergent validity with a loading factor of $>0.50$. Therefore, in preparing the questionnaire, adequate items can be made so that when some items have to be discarded, some items represent indicators in these variables.

\section{REFERENCES}

Bandura, A. (1977). Social Learning Theory. New Jersey: Prentice-Hall Publishers.

Cazan, A. M. (2012). Self-Regulated Learning Strategies-Predictors of Academic Adjustment. Procedia - Social and Behavioral Sciences, 33, 104-108. https://doi.org/10.1016/j.sbspro.2012.01.092.

Corno, L., \& Mandinach, E. B. (1983). The Role of Cognitive Engagement in Classroom Learning and Motivation. Educational Psychologist, 18(2), 88-108. https://doi.org/10.1080/00461528309529266.

Deal, T. E., \& Peterson, K. D. (2009). Shaping School Culture; Pitfalls, Paradoxes, \& Promises the Second Edition. New Jersey: John Wiley \& Sons, Inc.

Desmita. (2012). Psikologi Perkembangan Peserta Didik. Bandung: Remaja Rosdakarya.

Drever, J. (1986). Kamus Psikologi. Jakarta: PT. Bina Aksara.

Fasikhah, S. S., \& Fatimah, S. (2013). Self-Regulated Learning (SRL) dalam Meningkatkan Prestasi Akademik pada Mahasiswa. Jurnal Ilmiah Psikologi Terapan, 01(01), 145155. https://doi.org/10.22219/jipt.v1i1.1364.

Fettahlioğlu, P. (2011). The Analysis of Using Self-Regulated Learning Strategies According to gender factor. Procedia - Social and Behavioral Sciences, 15, 2748-2752. https://doi.org/10.1016/j.sbspro.2011.04.182.

George, J. M., \& Jones, G. R. (2005). Understanding and Managing Organizational Behavior. 
New York: Pearson Education.

Hair, J. F., Black, W. C., Babin, B. J., \& Anderson, R. E. (2014). Multivariate Data Analysis (7th ed.). England: Pearson Education Limited.

Harahap, A. C. P., \& Neviyarni S, D. (2018). Hubungan antara Self Efficacy dan Dukungan Sosial Orangtua dengan Self Regulated Learning serta Implikasinya terhadap Bimbingan dan Konseling. Jurnal ANSIRU PAI, 3(1), 46-62. http://dx.doi.org/10.30821/ansiru.v2i1.1627.

Hurlock, E. B. (1993). Perkembangan Anak. Jakarta: Erlangga.

Jakešová, J., \& Kalenda, J. (2015). Self-Regulated Learning: Critical-Realistic Conceptualization. Procedia - Social and Behavioral Sciences, 171, 178-189. https://doi.org/10.1016/j.sbspro.2015.01.105.

Kalenda, J., \& Vávrová, S. (2016). Self-Regulated Learning in Students of Helping Professions. Procedia - Social and Behavioral Sciences, 217, 282-292. https://doi.org/10.1016/j.sbspro.2016.02.086.

Kareshki, H. (2011). Relations among Perceptions of Classroom Activities and SelfRegulating Learning. Procedia - Social and Behavioral Sciences, 12, 409-413. https://doi.org/10.1016/j.sbspro.2011.02.050.

Labhane, C., \& Baviskar, P. (2015). Self-Concept and Emotional Intelligence: a Comparative Study of Arts and Science College Students. The International Journal of Indian Psychology, 2(2), 1-7. https://doi.org/10.25215/0202.012.

Lunenburg, F. C. (2011). Understanding Organizational Culture: a Key Leadership Asset. National Forum of Educational Administration and Supervision Journal, 29(4), 1-12. https://pdf4pro.com/amp/view/understanding-organizational-culture-a-keyleadership-asset-3ac53d.html.

Mihaela, V., \& Bratianu, C. (2012). Organizational culture modeling. Management \& Marketing. Challenges for the Knowledge Society, 7(2), 257-276. https://www.researchgate.net/publication/237137961_Organizational_culture_ modeling.

Motie, H., Heidari, M., \& Sadeghi, M. A. (2012). Predicting Academic Procrastination during Self-Regulated Learning in Iranian First Grade High School Students. Procedia Social and Behavioral Sciences, 69(Iceepsy 2012), 2299-2308. https://doi.org/10.1016/j.sbspro.2013.02.023.

Muis, K. R. (2007). The Role of Epistemic Beliefs in Self-Regulated Learning. Educational Psychologist, 42(3), 173-190. https://doi.org/10.1080/00461520701416306.

Mukhid, A. (2008). Strategi Self-Regulated Learning: Perspektif Teoritik. Tadris (Jurnal Pendidikan Islam). 3, 222-239. https://doi.org/10.19105/tjpi.v3i2.239.

Mulyadi, S., Basuki, A. M. H., \& Rahardjo, W. (2016). Student's Tutorial System Perception, Academic Self-Efficacy, and Creativity Effects on Self-Regulated Learning. Procedia - Social and Behavioral Sciences, 217, 598-602. https://doi.org/10.1016/j.sbspro.2016.02.059.

Nalah, A. B. (2014). Self-Concept and Students' Academic Performances in College of Education, Akwanga, Nasarawa State, Nigeria. World J Young Researchers, 3(2), 3137. http://dx.doi.org/10.1037/rnSAP0000005.

Ozan, M. B., \& Demir, C. (2012). The perception levels of teachers and students related to school culture metaphors according to different types of high schools. International Journal of Human Sciences, 9(2), 831-846. Retrieved from 
http://ezproxy.umsl.edu/login?url=http://search.ebscohost.com/login.aspx?dire

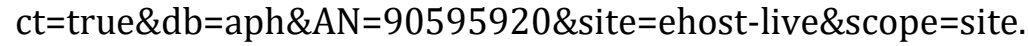

Pekrun, R., Goetz, T., Titz, W., \& Perry, R. P. (2002). Academic Emotions in Students' SelfRegulated Learning and Achievement: A Program of Qualitative and Quantitative research. Educational Psychologist, 37(2), 91-105. https://doi.org/10.1207/S15326985EP3702_4.

Permana, H. A., \& Latifah, L. (2015). Pengaruh Self Regulated Learning, Lingkungan Keluarga, dan Disiplin Belajar Terhadap Hasil Belajar Mata Pelajaran Pengantar Akuntansi Kelas X Akuntansi Smk Pl Tarcisius Semarang Tahun Ajaran 2014/2015. Economic Education Analysis Journal, 4(3), 789-802. https://journal.unnes.ac.id/sju/index.php/eeaj/article/view/8520.

Pintrich, P. R. (2000). The Role of Goal Orientation in Self-Regulated Learning. Handbook of Self-Regulation, 451-502. Retrieved from http://cachescan.bcub.ro/ebook/E1/580704/451-529.pdf.

Pintrich, P. R., \& Groot, E. V. De. (1990). Motivational and Self-Regulated Learning Component of Classroom Academic Performance. Journal of Educational Psychology, 82(1), 33-40. https://psycnet.apa.org/doi/10.1037/00220663.82.1.33.

Pratama, S., Siraj, A., \& T, M. Y. (2019). Pengaruh Budaya Religius dan Self Regulated terhadap Perilaku Keagamaan Siswa. Edukasi Islami: Jurnal Pendidikan Islam, 08(02), 331-346. http://dx.doi.org/10.30868/ei.v8i2.509.

Prijodarminto, S. (1994). Disiplin Kiat Menuju Sukses. Jakarta: Pradnya Paramita.

Risemberg, B. J. Z. dan. (1997). Self-regulatory dimensions of academic learning and motivation. In Handbook of Academic Learning: Constructing of Knowledge (pp. 105-125). San Diego: Academic Press.

Rosenberg, M., \& Kaplan, H. B. (1982). Social Psychology of the Self-Concept. New York: Basic Books.

Rusmita, I. D. A. Y., \& Badera, I. D. N. (2018). Budaya Organisasi sebagai Pemoderasi Pengaruh Kompetensi dan Locus of Control pada Kinerja Auditor Kantor Akuntan Publik di Provinsi Bali. E-Jurnal Akuntansi Universitas Udayana, 23(3), 1708-1735. https://doi.org/10.24843/EJA.2018.v23.i03.p04.

Sangeeta, R., \& Sumitra, N. (2012). Self-Concept; A Psychosocial Study on Adolescents. Journal of Multidisciplinary Research, 2(5), 49-61. http://www.zenithresearch.org.in/images/stories/pdf/2012/May/ZIJMR/5_ZIJ MR_Vol2_Issue5_May\%202012.pdf.

Savoji, A. P., Niusha, B., \& Boreiri, L. (2013). Relationship between Epistemological Beliefs, Self-Regulated Learning Strategies and Academic Achievement. Procedia - Social and Behavioral Sciences, 84, 1160-1165. https://doi.org/10.1016/j.sbspro.2013.06.719.

Schunk, D. H., \& Zimmerman, B. J. (1998). Self-Regulated Learning: From Teaching to SelfReflective Practice. New York: The Guilford Press.

Soufi, S., Damirchi, E. S., Sedghi, N., \& Sabayan, B. (2014). Development of Structural Model for Prediction of Academic Achievement by Global Self-Esteem, Academic SelfConcept, Self-Regulated Learning Strategies and Autonomous Academic Motivation. Procedia - Social and Behavioral Sciences, 114, 26-35. https://doi.org/10.1016/j.sbspro.2013.12.651. 
Subari. (1994). Supervisi Pendidikan dalam Rangka Perbaikan Situasi Mengajar. Jakarta: Bumi Aksara.

Sulisworo, D., Fitrianawati, M., Maryani, I., Hidayat, S., Agusta, E., \& Saputri, W. (2020). Students' Self-Regulated Learning (SRL) Profile Dataset Measured during Covid-19 Mitigation in Yogyakarta, Indonesia. Data in Brief, 33, 106422. https://doi.org/10.1016/j.dib.2020.106422.

Sungur, S., \& Takayya, C. (2006). Effects of Problem-Based Learning and Traditional Instruction on Self-Regulated Learning. The Journal of Educational Research, 99(5), 307-317. https://doi.org/10.3200/JOER.99.5.307-320.

Usher, E. L., \& Pajares, F. (2008). Self-Efficacy for Self-Regulated Learning: A Validation Study. Educational and Psychological Measurement, 68(3), 443-463. https://doi.org/10.1177/0013164407308475.

Vovides, Y., Sanchez-Alonso, S., Mitropoulou, V., \& Nickmans, G. (2007). The Use of ELearning Course Management Systems to Support Learning Strategies and to Improve Self-Regulated Learning. Educational Research Review, 2(1), 64-74. https://doi.org/10.1016/j.edurev.2007.02.004.

Zahrawati, F. (2020). Penerapan Model Problem based Learning untuk Meningkatkan Hasil Belajar osiologi Siswa. Indonesian Journal of Teacher Education, 1(2), 71-79. file://C:/Users/PC/Downloads/93-Article\%20Text-344-1-10-20200426.pdf.

Zahrawati, F., \& Faraz, N. J. (2017). Pengaruh Kultur Sekolah, Konsep Diri, dan Status Sosial Ekonomi Orang Tua terhadap Perilaku Konsumtif Siswa. Harmoni Sosial: Jurnal Pendidikan IPS, 4(2), 131-141. https://doi.org/10.21831/hsjpi.v4i2.9480.

Zahrawati, F., \& Nurhayati. (2021). The Challenge of Online Learning in Curriculum-2013 during COVID-19 Pandemic: Study of Social Science Teachers at MAN 2 Parepare. Sociological Education, 2(1), 9-14. https://doi.org/10.12345/socioedu.v2i1.380.

Zahrawati, F., \& Ramadani, A. N. (2021). Problematika Implementasi Kurikulum 2013 terhadap Proses Pembelajaran pada Masa Pandemik Covid-19. Bidayatuna : Jurnal Pendidikan Guru Madrasah Ibtidaiyah, 04(01), 59-74. https://doi.org/10.36835/bidayatuna.v4i1.901.

Zamroni. (2007). Pendidikan dan Demokrasi dalam Transisi (Prakondisi Menuju Era Globalisasi). Jakarta: PSAP Muhammadiyah.

Zimmerman, B. J. (1989). A Social Cognitive View of Self-Regulated Academic Learning. Journal of Educational Psychology, 81(3), 329-339. http://dx.doi.org/10.1037/0022-0663.81.3.329.

Zimmerman, B. J., \& Martinez-Pons, M. (1990). Student Differences in Self-Regulated Learning: Relating Grade, Sex, and Giftedness to Self-Efficacy and Strategy Use. Journal of Educational Psychology, 82(1), 51-59. https://doi.org/10.1037/00220663.82.1.51. 